\title{
BIOMASS BOTTOM ASH RECYCLING AS PAVEMENT BASE
}

\begin{abstract}
Adomas NETECKIS, Institute of Environment and Ecology, Agriculture Academy, Vytautas Magnus University, K. Donelaičio g. 58, LT-44248 Kaunas, Lithuania, adomas.neteckis@vdu.lt

Valdas PAULAUSKAS Institute of Environment and Ecology, Agriculture Academy, Vytautas Magnus University, K. Donelaičio g. 58, LT-44248 Kaunas, Lithuania. valdas.paulauskas@ vdu.lt (corresponding author)

Alfreda KASIULIENĖ Department of Civil, Environmental and Natural Resources Engineering, Luleå University of Technology, SE-971 87 Luleå, Sweden, alfreda.kasiuliene@gmail.com

Gerda JUNEVIČIŪTĖ, Institute of Environment and Ecology, Agriculture Academy, Vytautas Magnus University, K. Donelaičio g. 58, LT-44248 Kaunas, Lithuania. gerda.juneviciute@ vdu.lt

EU countries agreed upon increasing the use of renewable energy, which strongly stimulates usage of biofuels. Biomass ash is generated as a residue product in large volumes as a result of biomass combustion. Heavy metal content in the ashes is the main hinder for further ash utilization in agriculture, forestry and construction sector. Aim of this study was to assess potential of biomass ash to be used as pavement base, also to evaluate risks associated with heavy metals contained in ash as well as their leaching possibility. Ash elemental analysis showed that biomass was burned efficiently, and organic carbon content in ash samples was below $2 \%$. The limiting trace element was cadmium, which concentration in ash exceeded maximum permissible value, restricting ash recycling in forestry or agriculture. Leaching test showed that there is no threat to the environment when such waste material is used in road construction as base layer. All leaching values were below permissible concentrations or even below ICP detection limits. Compaction tests of layers made from gravel/ash mixtures revealed that biomass ash could be successfully used in road construction industry. Results showed that the strongest mixed layer was from $80 \%$ gravel and $20 \%$ ash. The compaction of this mixture was the highest, only the second best result showed pure $100 \%$ gravel, while the least compacted was $50 \%$ ash and $50 \%$ gravel mixture.
\end{abstract}

Keywords: biomass ash, waste recycling, pavement base, heavy metals, leaching

\section{INTRODUCTION}

The EU Strategy for Sustainable Development set the goal that $20 \%$ of energy should originate from renewable sources by 2020. Lithuania already has achieved this commitment in $2014-23.9 \%$ of the overall energy was produced from renewable resources, compared to an EU average of just 16\% (Lithuanian Biomass..., 2008, Bužinskienè, 2018). Furthermore, the EU has set ambitious climate and energy targets for 2030, including an EU-wide target for renewable energy of at least 27\% of final energy consumption (Sustainable and Optimal..., 2017). Biomass currently accounts for $8-15 \%$ of all energy produced in the world. This share is foreseen to reach $33-50 \%$ by 2050 (Vestin et al, 2012). On average, $95-97 \%$ of the biomass energy is recovered through direct combustion. This generates about 476 million tonnes of biomass ash worldwide per year, if the amount of biomass burnt equals to 7 billion tonnes with an average ash yield of $6,8 \%$ dry weight. Promoting the combustion of biomass will inevitably lead to an increase in ashes generated (Nunes et al., 2016, EU Directive..., 2018). In the nearest future humanity may face serious problems with the disposal of biomass ashes. Currently, wood ash is defined as non-hazardous waste and is therefore subject to non-hazardous waste management EU/LT standards and regulations. Energy companies usually deposit biomass ash in the local municipal landfills, as this is the simplest but maybe not always the cheapest way of non-hazardous waste disposal. Recycling of ash would be the best option in the future perspective. The spreading of ash on the surface of the land for fertilization or liming purposes is encouraged because of plant macronutrients and microelements returned back to the soil as well as strong alkaline (soil acidifying) properties. Utilization of biomass ash in forestry and agriculture is defined in the Regulations on Wood Ash Disposal and Use (Regulations on Wood..., 2014). Heavy metals (HM) can be the limiting factor for ash utilisation. Concentrations of HM in biomass ash can vary. Zinc and manganese as a rule exhibit the highest average concentrations in ash, and such trace elements as $\mathrm{Se}, \mathrm{Hg}, \mathrm{Cd}-$ the lowest (Table 1).

Table 1. Average concentrations of heavy metals in biomass ash

\begin{tabular}{l|c|c|c|c|c}
\hline Concentration & $<3 \mathrm{ppm}$ & $<25 \mathrm{ppm}$ & $<50 \mathrm{ppm}$ & $<110 \mathrm{ppm}$ & $>300 \mathrm{ppm}$ \\
\hline Element & $\mathrm{Se}, \mathrm{Hg}$ & $\mathrm{Cd}, \mathrm{Co}$ & $\mathrm{Mo}, \mathrm{Ni}, \mathrm{As}, \mathrm{Cr}$ & $\mathrm{Pb}, \mathrm{Cu}, \mathrm{B}$ & $\mathrm{Zn}, \mathrm{Mn}$ \\
\hline
\end{tabular}

Source: Someshwar, 1996.

The micro- and macroelement concentrations in ash depend upon the place of biomass growth as well as neighbouring sources of pollution: industrial plants, motorways, landfills (Benitez et al, 2001). Researchers have detected higher concentrations of HM in biomass ash originating in the east of the country than in other parts of Finland. Analysis

Copyright $\odot 2019$ The Authors. Published by Vytautas Magnus University. This is an open-access article distributed under the terms of the Creative Commons Attribution License (CC BY 4.0), which permits unrestricted use, distribution, and reproduction in any medium, provided the original author and source are credited. 
showed that this increase was influenced by biomass feedstock imported from large industrial districts of Russia, and this fact has been confirmed during long-term biomass ash studies in Finland (Moilanen and Issakainen, 2003). Alternative use of ash is actively investigated in Sweden, Germany, Denmark, France. Of all the EU countries, Sweden has the most advanced use of biomass for power generation. Swedish companies, including the energy sector, generate more than 1 million tons of ash annually, almost $80 \%$ of which is recycled; and thus ash waste does not end up in the landfills. In these countries ash is utilized in road construction industry, landfill reclamation, overlaying and filling of old mining sites or is included in concrete products (Lagerkvist and Lind, 2009; Bjurström and Herbert, 2009; Crillesen, 2010). The use of ash should not adversely affect the quality of the environment, and it is therefore necessary to know the physical, geotechnical properties of the ash and to follow established methods to ensure that leaching of HM is in accordance with the legislation (Nesterov et al., 2006).

Aim of this study was to assess potential of biomass ash to be used as pavement base, also to evaluate risks associated with heavy metals contained in ash as well as their leaching possibility.

\section{RESEARCH METHODS}

Biomass ash was sampled from ash waste containers before disposal at the landfill. Ashes were collected in 750 mL PE boxes and total weight of a composite sample ranged from 300 to 900 grams. The samples taken were labelled and brought to the laboratory for further analysis. The ash used in the tests was neither stabilized nor otherwise treated. The ash moisture content was determined by gravitometry with DBS 60-3 (Kern). The ash pH was measured with an Orion (Thermo Scientific) ionometer. Instrumental analysis of macroelements ( $\mathrm{Ca}, \mathrm{Mg}, \mathrm{K}$, and $\mathrm{P}$ ) and trace elements $(\mathrm{Zn}$, $\mathrm{Cu}, \mathrm{Ni}, \mathrm{Pb}, \mathrm{Cd}, \mathrm{Cr}$ ) was performed by ICP-OES using Perkin-Elmer Optima 8000 ICP-OES spectrometer. Samples were previously subjected to high-pressure mineralization in a CEM Mars 5 microwave mineralizer. Only pure reagents for chemical analysis were used throughout the experiment. Analysis of samples of known concentration was performed to ensure the reliability of the results. The element concentration, spectrophotometrically measured in the digestates, was expressed in ppm $(\mathrm{mg} / \mathrm{kg})$ on dry matter basis. Leaching test was performed following standardised EN 12457-2:2003 procedures referring to waste characterization by leaching at a liquid-to-solid $(\mathrm{L} / \mathrm{S})$ ratio of $10 \mathrm{~L} / \mathrm{kg}$. This procedure specifies a compliance test providing information on leaching of granular wastes and sludges under the experimental conditions specified hereafter, and particularly a liquid to solid ratio of $10 \mathrm{l} / \mathrm{kg}$ dry matter. It applies to waste which has a particle size below $4 \mathrm{~mm}$ without or with size reduction. This Standard has been developed to investigate mainly inorganic constituents from wastes. It does not take into account the particular characteristics of non-polar organic constituents. This procedure cannot be applicable to materials with water content or such a water affinity that a good mixing of the solid with the predetermined quantity of liquid is not achievable. Also it cannot be applicable to materials reacting with the leachant, leading, for example, to excessive gas emission, a solidifying effect or an excessive heat release. It should be noted, that in the case when waste crushing is applied, new surfaces are exposed which may lead to a change in leaching properties. All the above mentioned tests were performed in triplicate, the results of elemental analysis were calculated as the mean value of these replicates; values $\mathrm{p}<0.05$ considered as statistically significant.

After positive leaching test was achieved, ash recycling experiment was conducted in the private area in Kaunas district. Gravel $(0.32 \mathrm{~mm})$, ash $(0.56 \mathrm{~mm})$ and there mixtures were used as a construction frost-resistant layer under the $\mathrm{road} /$ pavement (Figure 1).

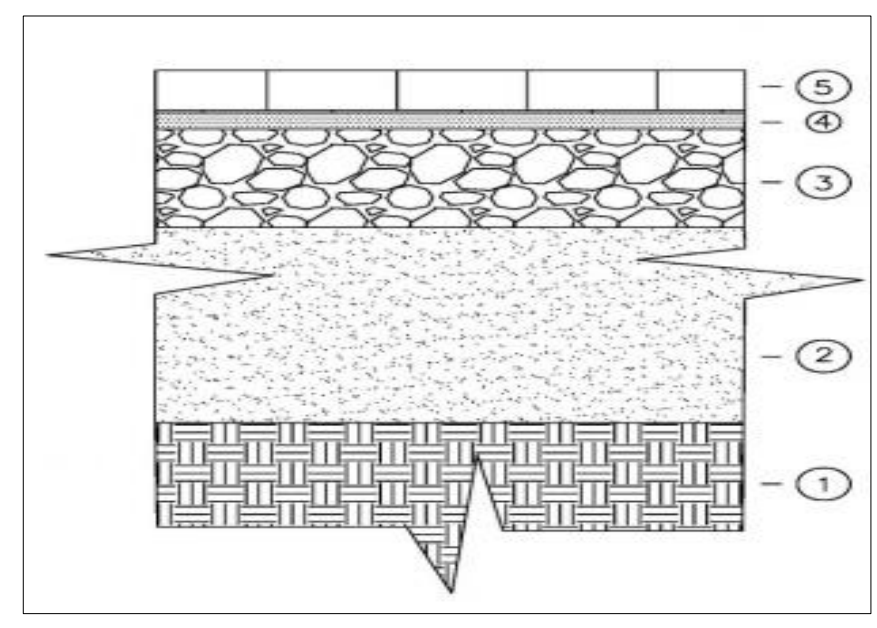

Figure 1. Road/pavement construction layout:

$$
\begin{aligned}
& 2 \text {-frost-resistant layer; other layers: } \\
& 1 \text { - compacted natural background layer; } \\
& 3 \text { - crushed stone (gravel) layer; } \\
& 4 \text { - smoothing blanket layer; } \\
& 5 \text { - top layer (bricks, stone, concrete, etc.) }
\end{aligned}
$$

Total amount of base materials used - $10 \mathrm{~m}^{3}$. Ash was obtained from Kaunas municipality biomass boiler 'Inkaras', gravel from 'Kvesu' quarry, Vilemai village, Kaunas district. The top-soil together with grass/litter layer was first removed. Then the ground/soil was excavated and the empty place was prepared, where a protective layer of frost-resistant substrate of different composition has been formed (Figure 2). 

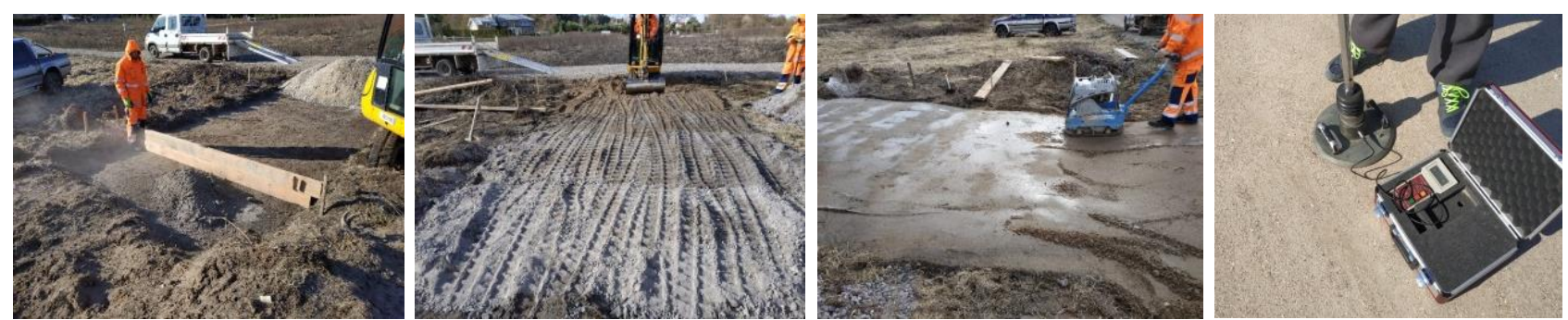

Figure 2. Construction process and measuring of compaction quality of frost-resistant base layer (pictures by Neteckis)

The test was performed in March 2019. Air temperature was 5-6 degrees above zero. The gravel/ash mixtures (P1P5, Table 2) were prepared and the base was formed with a mini excavator JCB 8016 (weight 1.6 tons). The surface of the formed layer was levelled by hand. After excavation, the bed bottom was vibrated with a Webwr vibrator (weight 200 $\mathrm{kg}$ ). Ground compaction depth was at least $40 \mathrm{~cm}$. After vibration, the bottom of the trench was divided into five equal parts, where mixed ash and gravel substrates were laid in different proportions (Table 2).

The selected test areas were separated by wooden boards to prevent different gravel/ash substrates from mixing together. Each sub-trial area was $1.75 \mathrm{~m}$ wide and $3 \mathrm{~m}$ long. Total area for the whole experiment was $27 \mathrm{~m} 2(3 \times 9 \mathrm{~m})$.

All 5 layers of the substrate were wetted enough with an equal amount of water and later vibrated with a Weber vibrator (weight $200 \mathrm{~kg}$ ). The compacted layers were left to stand for 4 weeks. A month later, compaction of a base layer was measured with a dynamic punch.

\section{RESEARCH RESULTS}

Biomass boilers can burn a variety of fuel - not only traditional firewood or straw, but also other types of biomass. All these fuels are considered as renewable energy sources and, according to an international agreement, $\mathrm{CO}_{2}$ from the combustion of such fuels is not considered to be a greenhouse gas. According to ISO 17225-1:2014 (2014), solid biofuels depending upon their origin are classified into: wood biomass (forest, plantation and other untreated wood; by-products and wastes from the wood processing industry, etc.); herbaceous biomass (agricultural and horticultural herbaceous biomass; by-products and waste from food and agro-processing industry, etc.); fruit biomass (fruits from orchards and horticulture; by-products and waste from fruit processing industry, etc.); biomass mixes and blends. The biofuel boiler plant "Inkaras" (Kaunas) uses both local wood biomass, also biofuel obtained from Belarus (Figure 3).

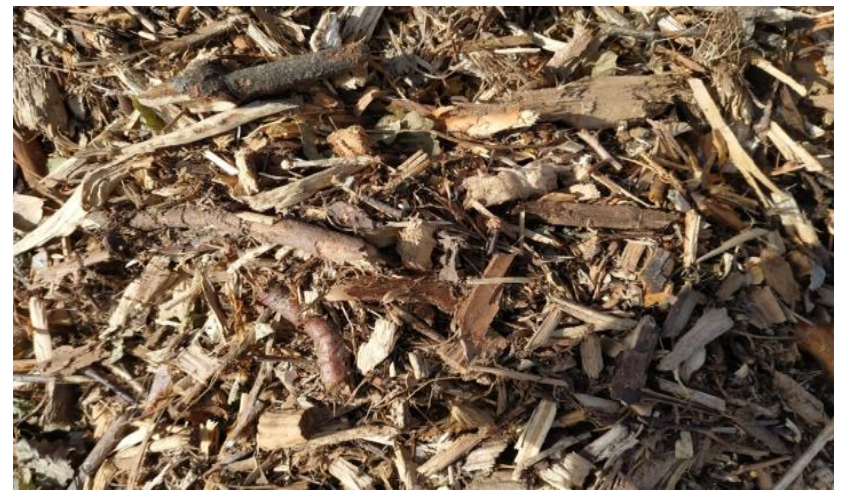

(a)

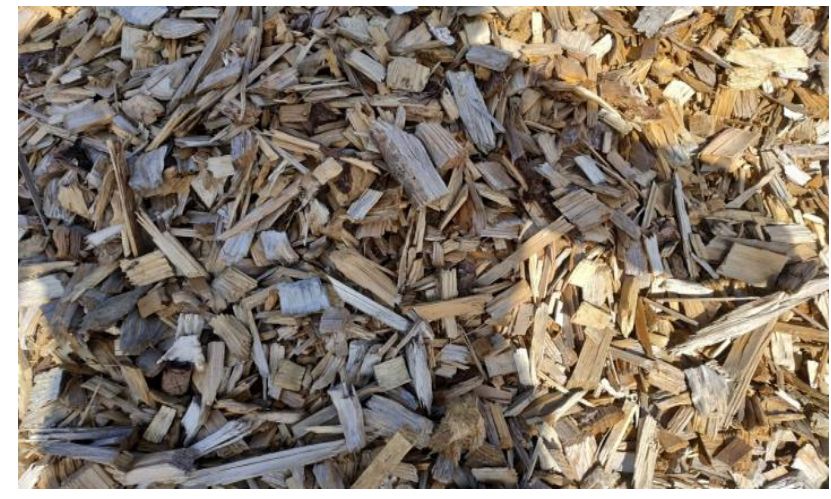

(b)

Figure 3. Different wood biomass burnt in "Inkaras" power plant: a) waste wood chips from Lithuania; b) wood chips from Belarus (pictures by Neteckis)

Local fuel mainly consists of logging forest waste - shredded residual branches, stumps, roots, etc. Higher quality chipped logs/wood is imported from Belarus. The boiler mainly burns wood fraction SM2, humidity 30-50\%. Ten-eleven full wood chip trucks are fuelled daily in the boiler house. About $20 \mathrm{~m}^{3}$ of ash is formed per week $\left(2\right.$ full $10 \mathrm{~m}^{3}$ waste containers). The amount of ashes generated depends upon the obtained biofuel quality/composition. If chips of SM3 fraction (sandy branches, leaves, other residual biowaste) are fired, the amount of ash produced is higher, while the amount of ash, when clean wood fuel (e.g. wood pellets) is supplied, is less than half lower.

Biomass ash is a residue of inorganic and organic matter formed during the combustion process. Most data can be found on wood ash. Typically wood ash consists of silicon $(\mathrm{Si})$, calcium $(\mathrm{Ca})$, magnesium $(\mathrm{Mg})$, potassium $(\mathrm{K})$, phosphorus (P), manganese (Mn), iron (Fe), zinc (Zn), sodium (Na) and boron (B) (Pärn et al, 2010; Vesterinen, 2003, Varnagirytė-Kabašinskienè et al, 2014), however, the amount of these elements in wood ash may vary due to unequal accumulation in different parts of trees. Deciduous trees are characterized by higher amounts of some inorganic compounds (as e.g. potassium containing) than coniferous, therefore the different elemental composition of ash also depends on the tree species. Ash has a high Ca concentration and can be used for soil acidification. Scientists agree that biomass ash can be used successfully in agriculture for liming acidic soils because it has the same or very similar effects 
to limestone (Lickacz, 2002; Lundstrom et al, 2003). Ash from solid biofuels can be successfully utilised for recycling and fertilizing not only in agriculture, but also in forestry (Pitman, 2006; Ozolinčius et al, 2006; Ozolinčius et al, 2007; Haglund, et al, 2008). Nevertheless, biomass ash is a waste material and it should be utilised in an environment friendly way.

Heavy metals in ash can pose threat to groundwater, soil and vegetation if leached out. Seeking to evaluate impact on the environment when ash is recycled as a base material for road, bicycle or pedestrian pavement construction purpose, macro- and micro-elemental composition analysis as well as leaching tests were carried out. Results showed that macronutrient content in ash samples was higher than minimum values recommended in Swedish regulations for ash onland application in agriculture and forestry. The limiting trace element was cadmium (8.3 ppm), which concentration in ash exceeded maximum permissible value, restricting ash recycling in forestry or agriculture. When trace element in ash exceeds the permissible limits, such waste cannot be used as fertiliser, so it means that it should follow safe disposal/landfilling or beneficial utilisation using alternatively technologies. Big variation in the chemical composition of the investigated ash samples showed, that ash qualitative parameters are highly dependent on biomass origin, its composition/quality as well as contaminants contained.

Batch leaching tests were used to examine the extraction capacity of various species of contaminants from solid to aqueous phase under neutral/natural leaching conditions. In order to better simulate the natural conditions and susceptibility of contaminants to release, a higher L/S ratio was used. Leaching tests showed that there is no threat to the environment when such waste material is used in road construction as base layer. Leaching values for the investigated trace elements (lead $(\mathrm{Pb})$, copper $(\mathrm{Cu})$, zinc $(\mathrm{Zn})$, cadmium $(\mathrm{Cd})$, arsenic (As), mercury $(\mathrm{Hg})$, nickel (Ni), molybdenum (Mo), antimony ( $\mathrm{Sb}$ ), chromium (Cr), barium (Ba), selenium (Se)), also for negative ions as chlorides, fluorides, sulphates, were below the permissible concentrations or even below the ICP detection limits.

An important indicator of ash quality is the organic carbon (OC) content. If the OC concentration is greater than $10 \%(100 \mathrm{~g} / \mathrm{kg})$, this indicates that biofuel in the furnace burns poorly and the combustion of the fuel in the boiler room is considered inefficient (Champbell, 1990). Therefore, it is necessary to improve the efficiency of the combustion process by ensuring an appropriate technological regime - optimum temperature in the furnace, sufficient amount of oxygen, combustion time of biofuel, humidity of the fuel feed, etc. The organic carbon content in ash of an efficient fuel combustion system is 1 to $2 \%$, whereas OC can reach up to $50-70 \%$ when biomass is burned inefficiently. Such low quality ash is difficult to stabilize, its self-hardening process is very slow, and decomposition of unburned organic compounds takes a long time. Ash elemental analysis showed that biomass in "Inkaras" boiler was burned efficiently organic carbon content in ash samples in all cases was below $2 \%$.

Table 2. Composition and physico-mechanical characteristics of the compacted frost-resistant layer of different mixtures

\begin{tabular}{c|c|c|c|c|c|c}
\hline $\mathrm{N}$ & Mixture & $\begin{array}{c}\text { Amount of gravel, } \\
\% \text { (by volume) }\end{array}$ & $\begin{array}{c}\text { Amount of ash, } \% \\
\text { (by volume) }\end{array}$ & $\begin{array}{c}\text { Dynamic } \\
\text { deformation } \\
\text { module Evd, } \\
\text { MN/m } \mathbf{m}^{2}\end{array}$ & $\begin{array}{c}\text { Static deformation } \\
\text { module Ev2, } \\
\text { MN/ } \text { m }^{2}\end{array}$ & $\begin{array}{c}\text { Layer compaction } \\
\%\end{array}$ \\
\hline 1 & P1 & 100 & 0 & 26 & 48 & $<97 *$ \\
\hline 2 & P2 & 80 & 20 & 28 & 54 & $<97$ \\
\hline 3 & P3 & 50 & 50 & 15 & 20 & $<97$ \\
\hline 4 & P4 & 20 & 80 & 16 & 22,5 & $<97$ \\
\hline 5 & P5 & 0 & 100 & 18 & 27,5 & $<97$ \\
\hline
\end{tabular}

*Compaction percentage for sand-gravel mixture should be $>97 \%$

In this study, a $30 \mathrm{~cm}$ thick frost-resistant base layer was prepared on a solid sandy ground basement. Such layer acts as a "cushioning" for natural ground movement during frost periods and prevents deformation of the topcoat. Natural subsoil bottom base was sand, and it was vibrated well enough to reach sufficient compaction. After formation of 5 frostresistant layers with different constituents, each of them was modified using tap water, vibrated and left for self-hardening. After four weeks, compaction value of the formed base layers was measured with a dynamic punch. Mixture composition of the five investigated frost-resistant layers and their compaction properties are provided in the Table 2 . It should be noted, that in all cases the compaction value of frost-resistant layers, due to the lower weight of vibrator used in this experiment, were below the standard requirements $(<97 \%)$, but the aim of this study was to carry out the comparative compaction tests of gravel mixtures with different ash content. After studying the compaction properties and detection of the road base deformation modules (dynamic and static), it was found that the strongest frost-resistant layer was obtained by mixing $80 \%$ gravel and $20 \%$ ash. The compaction of this mixture was the highest with Ev2 - $54 \mathrm{MN} / \mathrm{m}^{2}$, only the second best result showed pure $100 \%$ gravel layer $\left(\mathrm{Ev} 2-48 \mathrm{MN} / \mathrm{m}^{2}\right.$ ), and the least compacted was $50 \%$ ash and $50 \%$ gravel based layer (Ev2 - $\left.20 \mathrm{MN} / \mathrm{m}^{2}\right)$.

\section{CONCLUSIONS}

- Ash elemental analysis showed that biomass was burned efficiently - organic carbon content in the ash samples was below $2 \%$.

- Macronutrient content in ash samples was higher than minimum values recommended in Swedish regulations for ash onland application in agriculture and forestry. 
- The limiting trace element was cadmium, which concentration in ash exceeded maximum permissible value, restricting ash recycling in forestry or agriculture. When trace element in ash exceeds the permissible limits, such waste cannot be used as fertiliser, so it means that it should follow safe disposal/landfilling or beneficial utilisation using alternatively technologies.

- Leaching test showed that there is no threat to the environment when such waste material is used in road construction as base layer. All leaching values were below permissible concentrations or even below ICP detection limits.

- Compaction tests of frost-resistant base layer made from different gravel/ash mixtures revealed that biomass ash could be successfully used in road construction industry. Results showed that the strongest mixed base layer was from $80 \%$ gravel and $20 \%$ ash. The compaction of this mixture was the highest, only the second best result showed pure $100 \%$ gravel, the least compacted was 50\% ash and 50\% gravel based layer.

\section{REFERENCES}

1. Benitez E., Romero M., Gomez M., Gallardolaro F., Nogales R. 2001. Biosolid and Biosolid Ash as Sources of Heavy Metals in Plant-Soil System. Water, Air and Soil Pollution, Vol. 132, pp. 75-87. https://doi.org/10.1023/A:1012012924151

2. Bjurström H., Herbert R. 2009. The Swedish Ash Programme 2002-2008. Biomass, Wastes, Peat - Any Solid Fuel but Coal.

3. Bužinskienè, R. 2018. Evaluation of the Use of Renewable Energy Sources. In Lithuanian. Agricultural Sciences, Vol. 25(1), pp. 43-62. https://doi.org/10.6001/zemesukiomokslai.v25i1.3668

4. Campbell A. G. 1990. Recycling and Disposing of Wood Ash. Tappi Journal, Vol. 73(9), pp. 141-146.

5. Crillesen K. 2010. Overview of Management of MSWI Bottom Ashes in Europe, pp. 32-39.

6. EU Directive 2018/2001 of the European Parliament and of the Council of 11 December 2018 on the Promotion of the Use of Energy from Renewable Sources. 2018 (Renewable Energy Directive).

7. European standard EN 12457-2:2003. Characterization of Waste - Leaching - Compliance Test for Leaching of Granular and Sludges - Part 2: One Stage Batch Test at a Liquid to Solid Ratio of $10 \mathrm{~L} / \mathrm{kg}$ with Particle Size below $4 \mathrm{~mm}$.

8. Haglund, N., and Expert Group. 2008. Guideline for Classification of Ash from Solid Biofuels and Peat Utilised for Recycling and Fertilizing in Forestry and Agriculture. Published as a part of the Nordic Innovation project on new solid biofuel standards and guidelines. Available https://p29596.typo3server.info/fileadmin/Files/Documents/06_Publications/GUIDELINE_FOR_CLASSIFICATION_OF_AS H.pdf. (accessed on 03/09/2019).

9. International Standard ISO 17225-1:2014. Solid Biofuel. Fuel Specifications and Classes. Part 1. General Requirements. (LST EN ISO 17225-1:2014)

10. Lagerkvist A., Lind B. 2009. Use of Wood Ash for Road Stabilisation. In International Symposium on Environmental Issues and Waste Management in Energy and Mineral Production. Department of Environmental Quality, State of Oregon.

11. Lickacz J. 2002.Wood ash: An Alternative Liming Material for Agricultural Soils. Alberta Agriculture, Food and Rural Development.

12. Lithuanian Biomass Energy Association (LITBIOMA). 2008. Lithuanian Action Plan for the Promotion of Renewable Energy Sources 2010-2020. Available at: http://www.ena.lt/doc_atsi/Atsi_EI.pdf (accessed on 03/09/2019).

13. Lundstrom, U.S., Bain, D.C., Taylor, A.F.S., van Hees, P.A.W. 2003. Effects of Acidification and Its Mitigation with Lime and Wood Ash on Forest Soil Processes: A Review. Water Air Soil Poll. 3:5-28. https://doi.org/10.1023/A:1024115111377

14. Moilanen M., Issakainen J. 2003. Effect of Woody Peat Ash on Soil, Elemental Content of Forest Vegetation and Tree Growth. In Finnish. Forest Power Report, Vol. 162, No. 91.

15. Nesterov I., Jensen P. A., Dam-Johansen K. 2010. Literature Review: Incineration Bottom Ash Leaching Properties. 17 p.

16. Nunes L.J.R., Godina R., Matias J.C.O., Catalão J.P.S. 2019. Evaluation of the Utilization of Woodchips as Fuel for Industrial Boilers. Journal of Cleaner Production, Vol. 223, pp. 270-277. https://doi.org/10.1016/j.jclepro.2019.03.165

17. Ozolinčius R., Armolaitis K., Raguotis A., Varnagirytė I., Zenkovaitė J. 2006. Influence of Wood Ash Recycling on Chemical and Biological Condition of Forest Arenosols Journal of Forest Science, Vol. 52, pp. 79-86. https://doi.org/10.17221/10164-JFS

18. Ozolinčius, R., Varnagirytė-Kabašinskienė, I., Stakènas, V., Mikšys, V. 2007. Effects of Wood Ash and Nitrogen Fertilization on Scots Pine Crown Biomass. Biomass Bioenergy, Vol. 31, pp. 700-709. https://doi.org/10.1016/j.biombioe.2007.06.016

19. Pärn H., Mandre M., Ots K., Klõšeiko J., Lukjanova A., Kuznetsova T. 2010. Use of Biofuel Ashes in Forestry. Forestry Studies, Vol. 52, pp. 40-59. https://doi.org/10.2478/v10132-011-0082-x

20. Pitman R. M. 2006. Wood Ash use in Forestry - a Review of the Environmental Impacts. Forestry, Vol. 79(5), pp. 563-588. https://doi.org/10.1093/forestry/cpl041

21. Regulations on Wood Ash Disposal and Use. 2011. In Lithuanian. Ministry of Environment of the Republic of Lithuania, D1 14, State News, 5-168 (updated edition D1-572, 2014). Available at: https://www.etar.lt/portal/lt/legalAct/TAR.AAC696779441/elkzLbkTTE (accessed on 03/09/2019).

22. Risse L. M., Gaskin J. W. 2010. Best Management Practices for Wood Ash as Agricultural Soil Amendment.

23. Someshwar,A. V. 1996. Wood and Combination Wood-Fired Boiler Ash Characterization. Journal of Environmental Quality, Vol. 25(5), pp. 962-972. https://doi.org/10.2134/jeq1996.00472425002500050006x

24. Sustainable and Optimal Use of Biomass for Energy in the EU Beyond 2020. 2017. Final report. Available at: https://ec.europa.eu/energy/sites/ener/files/documents/biosustain_report_final.pdf (accessed on 03/09/2019). 
25. Varnagiryte-Kabašinskienè I., Armolaitis K., Stupak I., Kukkola M., Wójcik J., Mikšys V. 2014. Some metals in aboveground biomass of Scots pine stands in Lithuania. Biomass Bioenergy, Vol. 66, pp. $434-441$. https://doi.org/10.1016/j.biombioe.2014.03.047

26. Vesterinen P. 2003. Wood Ash Recycling State of the Art in Finland and Sweden. VTT Processes, Jyväskylä.

27. Vestin J., Arm M., Nordmark D., Lagerkvist A., Hallgren P., Lind B. 2012. Fly Ash as a Road Construction Material. In WASCON, Conference Proceedings. 